\title{
Impact Assessment of Human Activities on Runoff and Sediment of Beiluo River in the Yellow River Based on Paired Years of Similar Climate
}

\author{
Yi He${ }^{1}$, Fei Wang ${ }^{2,3}$, Peng Tian ${ }^{4 *}$, Xing-Min Mu${ }^{1,2,3 *}$, \\ Peng Gao ${ }^{2,3}$, Guang-Ju Zhao ${ }^{2,3}$, Yi-Ping Wu ${ }^{5}$ \\ ${ }^{1}$ College of Water Resources and Architectural Engineering, Northwest A\&F University, \\ Yangling 712100, Shaanxi, China \\ ${ }^{2}$ Institute of Soil and Water Conservation, Northwest A\&F University, \\ Yangling 712100, Shaanxi, China \\ ${ }^{3}$ Institute of Soil and Water Conservation, Chinese Academy of Sciences and Ministry of Water Resources, \\ Yangling 712100, Shaanxi, China \\ ${ }^{4}$ College of Natural Resources and Environment, Northwest A\&F University, \\ Yangling 712100, Shaanxi, China \\ ${ }^{5}$ School of Human Settlements and Civil Engineering, Xi'an Jiaotong University, \\ Xi'an 710049, Shaanxi, China
}

Received: 11 September 2015

Accepted: 3 November 2015

\begin{abstract}
Climate change and human activities influence runoff and sediment load in an integrated way. However, under similar climate conditions the variability in runoff and sediment load is mainly a result of human activities. In this study, the change trends of runoff and sediment load were detected with linear regression analysis for the Beiluo River on the Loess Plateau, China. The impact of human activities on runoff and sediment was examined under similar weather conditions based on continuous monthly data of climate and runoff and sediment load from 1958 to 2012 at the Zhuangtou Hydrological Station. The results showed that: 1) Annual runoff and sediment load varied greatly and declined significantly in the study period, but precipitation and potential evapotranspiration $\left(\mathrm{ET}_{0}\right)$ estimated by the Food and Agriculture Organization (FAO) Penman-Monteith Method had no significant trend.

2) The paired periods with similar precipitation and $\mathrm{ET}_{0}$ were selected if they had similar annual amounts (less than $2 \%$ ) and similar changing process controlled by monthly data $(\mathrm{P}<0.05)$. It has been demonstrated that the decreases of runoff and sediment load were mostly $(60 \%, 70 \%, 75 \%)$ induced by human activities within the paired periods.
\end{abstract}

$\overline{* e-m a i l: x m m u @ m s . i s w c . a c . c n}$ pengtian@nwsuaf.edu.cn 
3) Evidence on the impact of human activities on normalized difference vegetation index (NDVI) change and sediment reduced by soil and water conservation practices could explain the runoff and sediment load change in this basin. The data indicated that approximately $46 \mathrm{Mt}$ of sediment was deposited annually from 1960-99 as a result of soil and water conservation structures.

Keywords: human activities, Beiluo River Basin, paired-periods with similar weather condition, runoff, sediment load

\section{Introduction}

Overland flow-driven soil erosion is a critical environmental issue, leading to sedimentation of waterways, ecological degradation, nutrient loss, etc. [1]. The erodible material produced by the soil erosion process is transported into rivers, resulting in high sediment deposition. Sediment transfer in rivers is a key component of the global denudation system [2]. Streamflow data are useful for regional climatic and hydrologic investigations. Streamflow and sediment load provide useful information on studying soil erosion and sediment delivery [3]. The changes of runoff and sediment load are mainly caused by natural climate variability and human activities (e.g., land-use change and dam construction), which has been demonstrated in the major river catchments across the world such as the Nile [4], the Colorado [5], the Yangtze [6], and the Yellow [7].

The Yellow is the second-longest river in Asia, notable for its large amount of sediment and relatively small amount of runoff. In recent years, human activities have significantly changed the process of sediment and runoff in the river, especially on the Yellow, where it has become increasingly pronounced in the past 90 years $[8$, 9]. Most studies on runoff and sediment load are based on data comparison $[2,10]$ or modeling analysis $[11,12]$. These two methods have assisted in understanding the runoff and sediment load variability, but they are quite different in theory and parameters used. For example, the rainfall-runoff and rainfall-sediment statistical model is still controversial when dividing the distinct transition point of runoff or sediment discharge time series by the impacts of human activities, resulting in different division periods showing differing results $[13,14]$. Therefore, it is difficult to draw general conclusions from these studies due to their empirical nature. Furthermore, although the mechanisms of runoff and discharge are clear in distributed hydrological models [15], the great spatial variability in the model parameters is a challenge. Current models do not consider the variation of precipitation and evaporation comprehensively in the divided period. The changes of runoff and sediment load under a changing environment can be attributed to both climate change and human activities. Many studies [16-19] used double mass curve to detect the impact of climate change and human activity on runoff and sediment load in different river basins. Dong et al. [20], who assumed a period can be considered the reference period of time series in which streamflow is less affected by human activities, analyzed the relative effects of human activities and climate change on the river runoff using a SWAT model. Zhao et al. [21] used both Budyko's curve and linear regression to evaluate the potential impacts of climate variability and human activities on annual streamflow in the middle reaches of the Yellow River basin. To isolate the effects of human activities, we proposed selecting two specific time periods with different intensities of human activities but similar climatic conditions (denoted as 'paired periods with similar climate'). The loess plateau had been experiencing severe loss of natural vegetation from the 1960s to the 1980 s mainly due to inappropriate human activities and climate warming. The objective of this study is to quantify the effects of climate change and human activities separately using the above approach and investigate how discharge and sediment yield varied during 1958 through 2012 .

\section{Data and Methods}

\section{Study Area}

The Beiluo River is $680 \mathrm{~km}$ long and is the secondlongest tributary of the Wei River in the Yellow River. The Beiluo River Basin $\left(26905 \mathrm{~km}^{2}\right)$ is located in the center of the Loess Plateau $\left(34^{\circ} 39^{\prime}-37^{\circ} 18^{\prime} \mathrm{N}, 107^{\circ} 33^{\prime}-110^{\circ} 10^{\prime} \mathrm{E}\right)$ in China. The basin encompasses parts of 18 counties across Gansu and Shaanxi provinces. A digital elevation model (DEM) and location of this basin is shown in Fig. $1(\mathrm{a}, \mathrm{b})$. The total area of soil erosion in this basin has reached nearly $72 \%$ of the basin total land cover, making the basin one of the most soil-eroded areas of the Loess Plateau and a major source of coarse sediment to the Yellow River. This area has thick loess layers. The particle composition is mainly fine sand, silt, and clay. The loess has high porosity and is prone to landslides. The soil is typical black loam soil with a loose structure that is readily degraded [22].

The climate of the Beiluo River Basin is continental monsoonal, with an average annual precipitation ranging from 400 to $600 \mathrm{~mm}$ and an average annual air temperature ranging from 8.0 to $12.0^{\circ} \mathrm{C}$ [23]. The average annual runoff and sediment load were $8.17 \times 10^{8} \mathrm{~m}^{3}$ and $0.71 \times 10^{8} \mathrm{t}$, respectively, from $1958-2012$. The average sediment concentration was $100 \mathrm{~kg} \mathrm{~m}^{-3}$ (Ministry of Water Resources of China, 2013). 


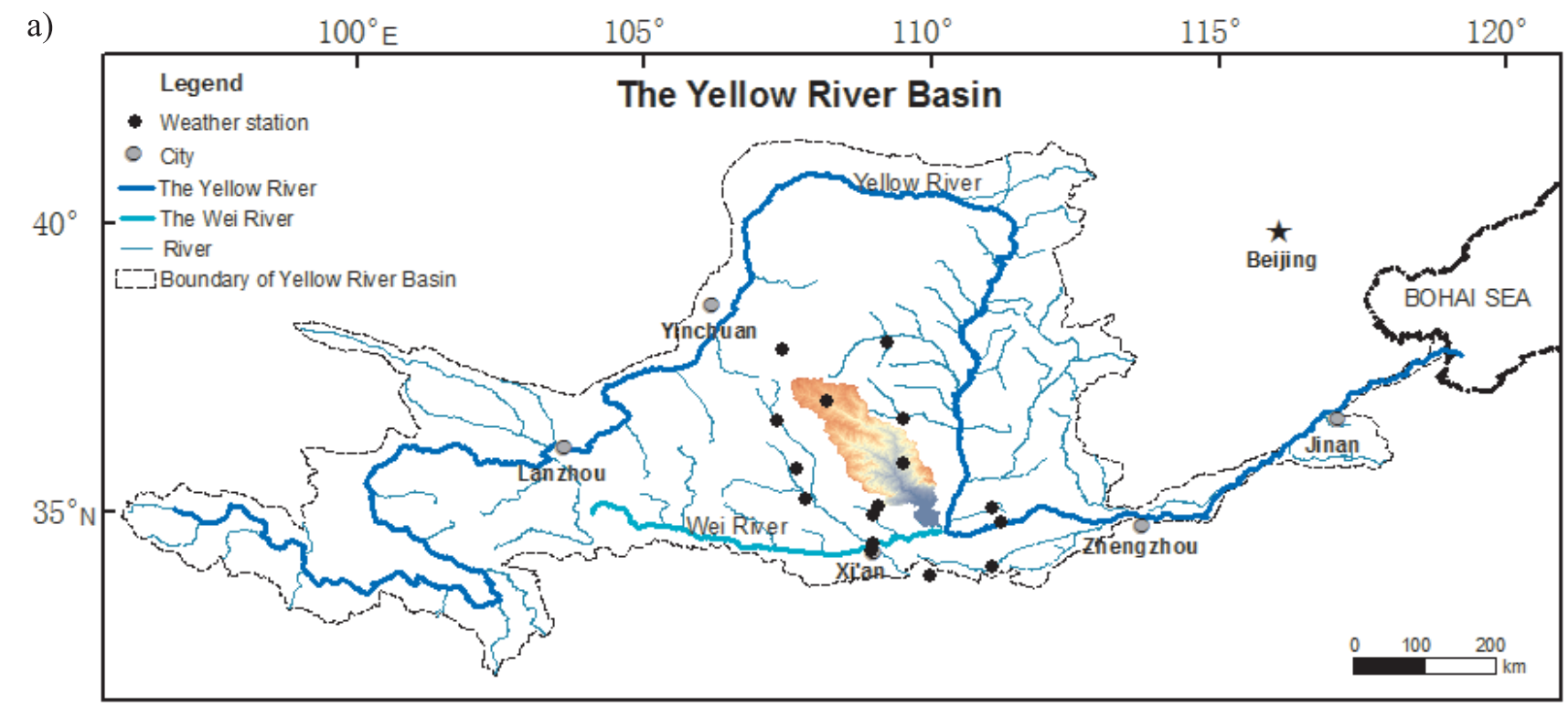

b) $\quad 108^{\circ} \mathrm{E} \quad 109^{\circ} \quad 110^{\circ}$

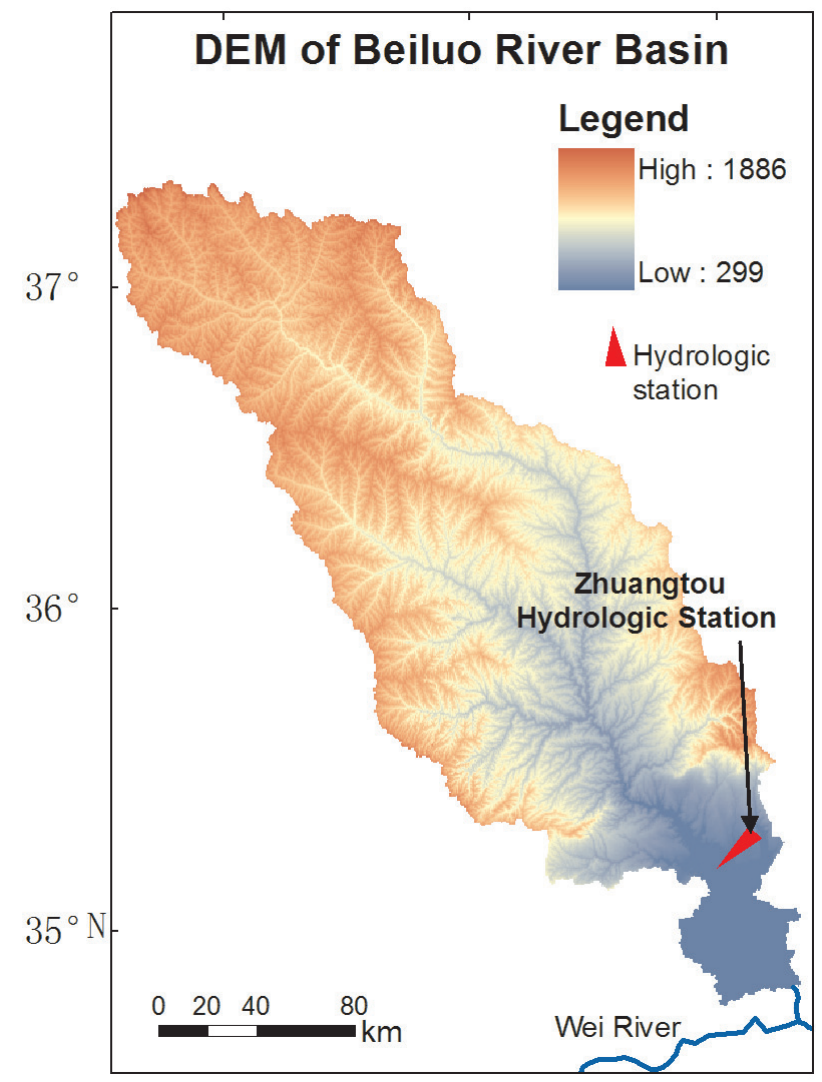

Fig. 1. Location of the Beiluo River Basin in the Yellow River, China.

\section{Data Collection}

The meteorological data were collected from 16 meteorological stations located within 120 kilometers of the Beiluo River Basin (apart from the mountain station) (Fig. 1a). The data, provided by the National Meteorological Information Centre (NMIC), include monthly precipitation $\left(\mathrm{P}_{\mathrm{m}}, \mathrm{mm}\right)$, maximum temperature
(TMX, ${ }^{\circ} \mathrm{C}$ ), minimum temperature $\left(\mathrm{TMN},{ }^{\circ} \mathrm{C}\right)$, relative humidity (RH, \%), wind speed (WS, $\mathrm{m} \mathrm{s}^{-1}$ ), and sunshine duration (SD, h) from 1958 to 2012. The dataset has been quality assured by NMIC. We performed further routine quality assessment and error correction procedures on the data following methods described by Peterson et al. [24]. The potential evapotranspiration of the Beiluo River Basin was calculated using the Penman-Monteith Method recommended by the Food and Agriculture Organization (FAO) [25]. The potential evapotranspiration and precipitation were regionally averaged based on the monthly records of stations upstream of the Zhuangtou Hydrological gauge Station (ZHS) using the spatial interpolation method. Annual potential evapotranspiration and precipitation were cumulated by month. Annual streamflow (in $10^{8} \mathrm{~m}^{3}$ ) and sediment load (in $10^{8} \mathrm{t}$ ) data at ZHS from 1958 to 2012 were obtained from the Chinese River Streamflow and Sediment Communiqués, Ministry of Water Resources, China (MWR).

The Global Inventory Monitoring and Modeling Studies (GIMMS) normalized difference vegetation index (NDVI) dataset was derived from the NOAA's advanced very high resolution radiometer (AVHRR) (http://www.noaa.gov, the dataset was downloaded from http://westdc.westgis. ac.cn), which provides information on the monthly changes in terrestrial vegetation from August 1981 to December 2006. Because of incomplete data in 1981, data from 1982 to 2006 were employed. The GIMMS data are based on a 15-day interval with $8 \mathrm{~km}$ spatial resolution [26]. To further eliminate the influence of clouds, atmosphere, and solar altitude angle, the international universal maximum value composites (MVCs) technique was used to calculate monthly maximum NDVI [27], which selects the highest NDVI at each pixel from GIMMS NDVI (15-day interval) [28]. The vegetation in the study area is most developed during the productive months of June to September. The vegetation change is usually small from October to the following May. The NDVI values of the four productive 
months can best reflect the long-term change of vegetation cover during the year. Therefore, the NDVI from June to September of each year was calculated using the MVCs method and this value was used as an indicator of the annual vegetation growth of the study area.

Soil and water conservation data ranging from 1960 to 1999 was obtained from the Soil and Water Conservation Data Compilation of the Yellow River, compiled by the Upper and Middle Yellow River Bureau in 2010. The dataset covers some general characteristics of the Beiluo River Basin, as well as biological conservation measurements such as man-made forest, grass-planting and hillside closures, and structural measures such as terraces, reservoirs, check dams, and key projects for gully control.

\section{Principle and Methods}

\section{Principle}

The water balance of the watershed can be expressed as:

$$
\mathrm{P}=\mathrm{R}+\mathrm{Wg}+\mathrm{Ws}+\mathrm{ETc}+\delta \mathrm{W}
$$

...where $\mathrm{P}$ is area precipitation, $\mathrm{R}$ is surface runoff, $\mathrm{Wg}$ is underground runoff, Ws is soil water storage, ETc is actual evapotranspiration, and $\delta \mathrm{W}$ is the change in water storage of engineered structures such as reservoirs.

Considering the specific hydrogeological conditions of the study area:

1) As there is a thick soil layer, a deep water table [29] and little recharge underground runoff from the limited infiltration [30], Wg is assumed to be approximately 0 .

2) There is little vegetation cover in the Beiluo River Basin, the infiltration capacity of surface soil is weak, and the main surface runoff is generated in the infiltration-excess manner; rainfall is characterized by heavy rainfall with high intensity and short duration [31], and therefore Ws can be ignored.

3) The water in reservoirs mainly supply the needs of people's daily lives and $\delta \mathrm{W}$ can be considered human impact.

Therefore, from a long process, equation (1) can be simplified to:

$$
\mathrm{P}=\mathrm{R}+\mathrm{ETc}
$$

...where $\mathrm{P}$ is area precipitation, $\mathrm{R}$ is surface runoff, and ETc is actual evapotranspiration.

$$
\mathrm{ETc}=\mathrm{k} \times \mathrm{ET}_{0}
$$

...where ETc is actual evapotranspiration, $\mathrm{k}$ is the coefficient, and $\mathrm{ET}_{0}$ is potential evapotranspiration. When under adequate water supply, $\mathrm{k}=1$ and $\mathrm{ETc}=\mathrm{ET}_{0}$. We assumed that $\mathrm{k}$ did not change for the same land under similar weather conditions and that the vegetation change induced by human could change $\mathrm{k}$. We analyzed $\mathrm{ET}_{0}$ instead of ETc and it was implied that the faster change in $\mathrm{ET}_{0}$ than the natural evolution of ETc is also the result of human activities.

\section{FAO Penman-Monteith Method}

The FAO Penman-Monteith (PM) approach to estimate evapotranspiration $\left(\mathrm{ET}_{0}, \mathrm{~mm} \mathrm{day}^{-1}\right)$ is regarded as a global standard and is presented in the FAO-56 report [25]. In this study, monthly potential evapotranspiration was calculated according to Allen et al. [25]. Monthly potential evapotranspiration was calculated by multiplying $\mathrm{ET}_{0}$ with the number of days in that month [32].

\section{Spatial Interpolation Method}

Spatial interpolation methods are developed for specific data types or a specific variable [33, 34]. In this study, the Disjunctive Kriging (DK) spatial interpolation method was selected to calculate the spatially averaged precipitation and potential evapotranspiration for the Beiluo River Basin.

\section{Trend Detection}

Parametric and non-parametric methods have been developed and applied successfully in hydro-climatic field analysis because of their ability to detect the physical relationships between ecological elements [8, 35]. However, they require more detailed data than other methods, which may be difficult to provide, as well as clear descriptions of processes, which might not yet have been developed [2]. This study uses a linear regression method to detect precipitation trends, potential evapotranspiration, runoff, and sediment load [36, 37].

\section{Accumulative Anomaly Curve to Detect Stage}

The accumulative anomaly was used to detect the trends and stages in annual precipitation $(\mathrm{P})$, sediment load $(\mathrm{S})$, runoff $(\mathrm{R})$, sediment concentration (SC), and evapotranspiration $\left(E_{0}\right)$. For data series $Y_{d i}(i=1,2, \ldots n)$, the accumulative anomaly method can be expressed as follows:

$$
Y_{\text {mean }}=\frac{1}{\mathrm{n}} \sum_{i=1}^{n} Y_{\mathrm{di}}
$$

$$
Y_{\mathrm{a}, \mathrm{i}}=\frac{Y_{d i}}{Y_{\text {mean }}}=-1,=1,2, \ldots, \mathrm{n}
$$

$$
Y_{0,1}=Y_{\mathrm{a}, 1}
$$

$$
Y_{0, \mathrm{~m}}=Y_{0, \mathrm{~m}-1}+Y_{\mathrm{a}, \mathrm{m}}, \mathrm{m}=2,3, \ldots, \mathrm{n}
$$


Table 1. Paired periods with similar precipitation and potential evapotranspiration conditions defined in this study.

\begin{tabular}{|c|c|c|c|}
\hline Type & $\begin{array}{c}\text { annual precipitation (three or five consecutive } \\
\text { years total precipitation) }\end{array}$ & $\begin{array}{c}\text { annual } \mathrm{ET}_{0} \text { (three or five } \\
\text { consecutive years total } \mathrm{ET}_{0} \text { ) }\end{array}$ & $\begin{array}{c}\text { apart years between pair } \\
\text { years (pair periods) }\end{array}$ \\
\hline Difference & less than $2 \%$ & less than $2 \%$ & $\begin{array}{c}\text { more than three or five } \\
\text { years apart }\end{array}$ \\
\hline
\end{tabular}

...where $\mathrm{Y}_{\text {mean }}, \mathrm{Y}_{\mathrm{di}}, \mathrm{Y}_{\mathrm{a}, \mathrm{i}}, \mathrm{Y}_{\mathrm{a}, \mathrm{m}}, \mathrm{Y}_{0,1}$, and $\mathrm{Y}_{0, \mathrm{~m}}$ are the average values for the data series, original data at year 1 and anomaly normalized value, accumulating anomaly normalized values at year 1 and $\mathrm{m}$, respectively. Cumulative anomalies of above factors were plotted to afford a visual distinguishing of the turning year when an obvious change in these factors had approximately happened [38].

\section{Approach of Paired Periods with Similar Climate}

Because precipitation is the main source of runoff and the main driving force of erosion, paired periods with similar precipitation and potential evapotranspiration conditions (SPEC) were selected to conduct the analysis $[38,39]$. To define paired periods, we paired two years, three consecutive-year periods, and five consecutiveyear periods with SPEC as the following conditions were applied (Table 1):

1) the two years, three consecutive years, and five consecutive years should have precipitation that differs by less than $2 \%$;

2) potential evapotranspiration should differ by less than $2 \%$

3) the two and five consecutive years should be more than five years apart, while three consecutive years should be more than three years apart.

Because the evolution of natural landforms and vegetation is quite slow, the changes to runoff and sediment load in an SPEC pair are mainly induced by human activities. This is a significant assumption for the study area, because it is well known that individual rainfall events can contribute approximately $60 \%$ to $90 \%$ of the yearly total rainfall [40]. Though the individual rainfall events are more functional to describe the impacts of rainfall on runoff and sediment generation in its influenced area, the rainfall events are very uneven in space and thus it is difficult to use data of events in the whole basin. Therefore, we used monthly data of precipitation and $\mathrm{ET}_{0}$ for identifying similar weather conditions of two or several years at the regional scale.

\section{Results}

\section{Runoff and Sediment Load}

The statistics for runoff, sediment load, sediment concentration, precipitation, and potential evapotranspiration are shown in Table 2. The mean annual runoff, sediment concentration, and sediment load were $8.17 \times 10^{8} \mathrm{~m}^{3}, 100.0 \mathrm{~kg} \mathrm{~m}^{-3}$, and $0.71 \times 10^{8} \mathrm{t}$, respectively. The difference between the maximum and minimum values for each variable was large. The runoff in 1964 was 5.76 times that in 1995 , the sediment concentration in 1977 was 155.1 times that in 2008, and the sediment load in 1994 was 328.75 times that in 2008. The coefficients of variation $(\mathrm{CVs})$ of runoff, sediment concentration, and sediment load were $0.37,0.74$, and 0.86 , respectively, strongly suggesting that the runoff and sediment changes are highly unstable.

\section{Variation of Precipitation and Potential Evapotranspiration}

Potential evapotranspiration and precipitation are the main climate variables that influence runoff and sediment. Precipitation is the driving force of soil erosion and sediment delivery, and it is also the water source for runoff and soil moisture in this region. In the Beiluo River Basin mean annual precipitation and potential evapotranspiration were $516.4 \mathrm{~mm}$ and $917.5 \mathrm{~mm}$, respectively (Table 2). The maximum precipitation (798.4 mm) in 1964 was 2.29 times the minimum precipitation $(349.2 \mathrm{~mm}$ ) in 1997 , and the $\mathrm{CV}$ for precipitation was 0.18 . The maximum recorded mean potential evapotranspiration in 1997 (1025.7 mm) was 1.36 times the minimum recorded value in 1964 $(752.1 \mathrm{~mm})$, with a low CV of 0.06 . The precipitation and

Table 2. Statistics for runoff (R), sediment load (S), sediment concentration (SC), precipitation $(\mathrm{P})$, and potential evapotranspiration $\left(\mathrm{ET}_{0}\right)$ of the Beiluo River in 1958-2012.

\begin{tabular}{|c|c|c|c|c|c|}
\hline \multirow{2}{*}{ Statistic } & $\mathrm{R}$ & $\mathrm{S}$ & $\mathrm{SC}$ & $\mathrm{P}$ & $\mathrm{ET}_{0}$ \\
\cline { 2 - 6 } & $10^{8} \mathrm{~m}^{3}$ & $10^{8} \mathrm{t}$ & $\mathrm{kg} \mathrm{m}^{-3}$ & $\mathrm{~mm}$ & $\mathrm{~mm}$ \\
\hline Mean & 8.17 & 0.71 & 100.0 & 516.4 & 917.5 \\
\hline Minimum & 3.50 & 0.01 & 1.87 & 349.2 & 752.1 \\
\hline (Year) & $(1995)$ & $(2008)$ & $(2008)$ & $(1997)$ & $(1964)$ \\
\hline Maximum & 20.15 & 2.63 & 290.0 & 798.4 & 1025.7 \\
\hline (Year) & $(1964)$ & $(1994)$ & $(1977)$ & $(1964)$ & $(1997)$ \\
\hline Median & 7.46 & 0.49 & 95.7 & 501.6 & 923.7 \\
\hline $\begin{array}{c}\text { Standard } \\
\text { deviation }\end{array}$ & 2.99 & 0.61 & 73.6 & 92.2 & 53.8 \\
\hline $\begin{array}{c}\text { Confidence } \\
\text { levels (95\%) }\end{array}$ & 0.81 & 0.16 & 19.9 & 24.9 & 14.5 \\
\hline $\begin{array}{c}\text { Coefficients } \\
\text { of Variation }\end{array}$ & 0.37 & 0.86 & 0.74 & 0.18 & 0.06 \\
\hline
\end{tabular}




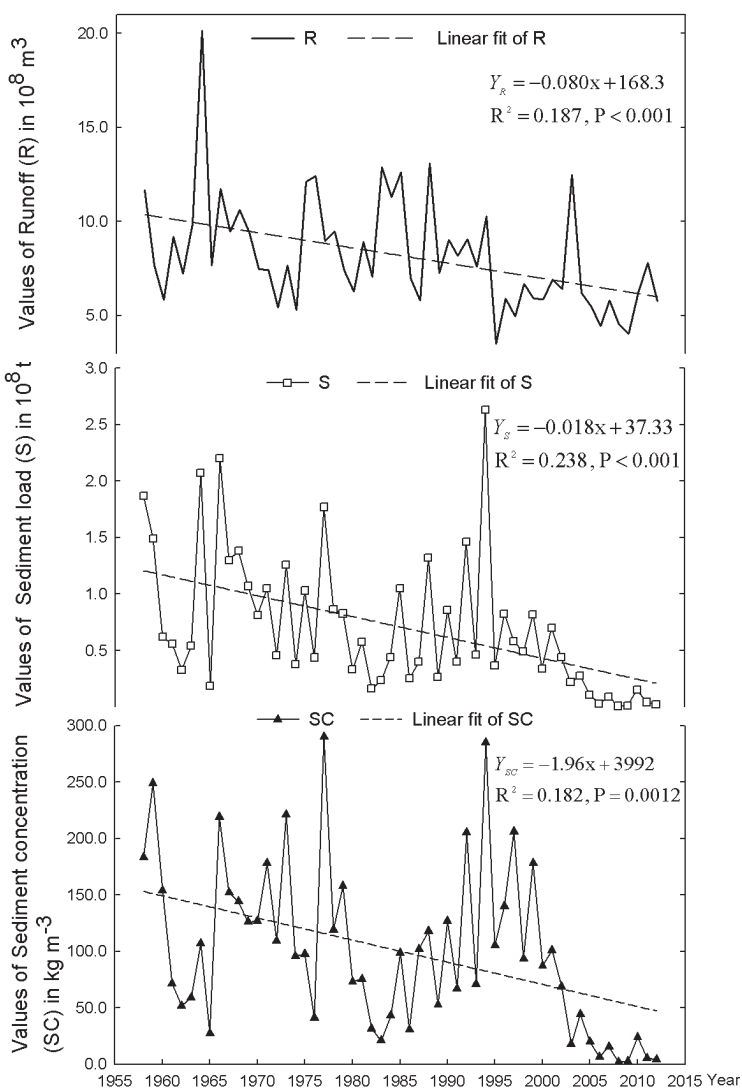

Fig. 2. Annual runoff, sediment concentration, and sediment load change in 1958-2012.

potential evapotranspiration were more stable than runoff, sediment concentration, and sediment load.

\section{Trends}

The annual sediment concentration, annual runoff, and sediment load had significant trends with a linear decline from 1958 to 2012 (Fig. 2). The average rate of decline of annual sediment concentration, annual runoff, and sediment load were $1.96 \mathrm{~kg} \mathrm{~m}^{-3} \mathrm{yr}^{-1}, 0.08 \times 10^{8} \mathrm{~m}^{3} \mathrm{yr}$ ${ }^{1}$, and $0.18 \times 10^{8}$ tyr $^{-1}$, respectively. There was significant $(\mathrm{P}<0.001)$ synchronized variation both between the annual runoff and sediment load, and annual sediment concentration and sediment load.

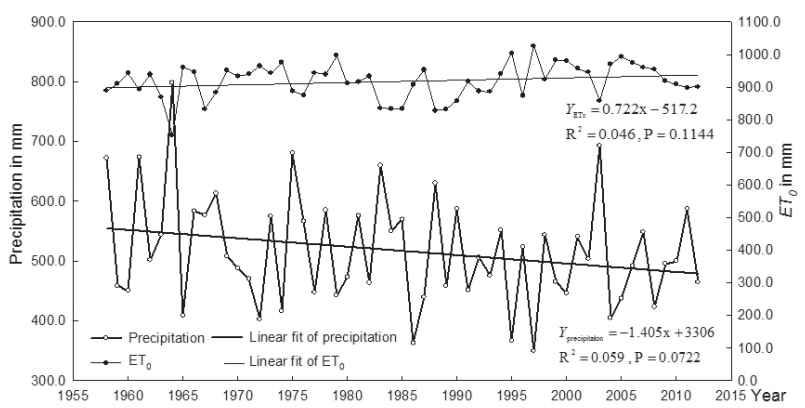

Fig. 3. Annual precipitation and $\mathrm{ET}_{0}$ change in 1958-2012.
Annual precipitation declined $(\mathrm{P}=0.0722)$ during the study period, while annual potential evapotranspiration had no significant trend (Fig. 3).

\section{Stages}

The mass curve of anomaly values describes the change process of a particular parameter by comparing it with the mean value of that parameter over the whole study period. If the observed data from a given year is bigger than the overall mean, the anomaly values will be positive and the mass curve will rise.

Over the whole study period, the mass curves of potential evapotranspiration showed the changes of declining first and then rising; the changing points of $\mathrm{ET}_{0}$ was in 1993 (Fig. 4). This indicates that mean annual ET before 1993 were smaller than the mean for the whole period, but that after 1993 they were higher than the mean of the whole period. The mass curve of precipitation was complex with many short-time up and down phases.

The river characteristics displayed similar changes, but were much more complex than $\mathrm{ET}_{0}$ and precipitation (Fig. 4). Base on the rules that were applied to detect stages from the mass curves of anomalies of normalized runoff, sediment load, and sediment concentration, four stages were determined. In the first stage (1958 to 1979), mean precipitation was $539.3 \mathrm{~mm}$, more than the mean value for the whole process $(516.4 \mathrm{~mm})$, but the mean annual $\mathrm{ET}_{0}$ was $916.5 \mathrm{~mm}$, with many short-time up and down phases (a little more than the whole period). Mean R, S, and SC were $9.27 \times 10^{8} \mathrm{~m}^{3}, 1.02 \times 10^{8} \mathrm{t}$, and $135.5 \mathrm{~kg} \mathrm{~m}^{-3}$, respectively - all more than the mean values for the whole period. In Stage II (from 1980 to 1990), the mean precipitation and $\mathrm{R}$ were $524.5 \mathrm{~mm}$ and $9.20 \times 10^{8} \mathrm{~m}^{3}$, respectively - more than the mean value for the whole process, while $\mathrm{ET}_{0}, \mathrm{~S}$, and $\mathrm{SC}$ were less than those for the whole period. The characteristics in Stage III (from 1991 to 1998), the mean $\mathrm{ET}_{0}(932.2 \mathrm{~mm}), \mathrm{S}$ $\left(0.90 \times 10^{8} \mathrm{t}\right)$, and $\mathrm{SC}\left(146.6 \mathrm{~kg} \mathrm{~m}^{-3}\right)$ were higher than the mean for the whole period, while the mean $\mathrm{R}$ and precipitation were less than those for the whole period. The mean precipitation in Stage IV (from 1999 to 2012) was $500.1 \mathrm{~mm}$, or about $3 \%$ less than that for the whole

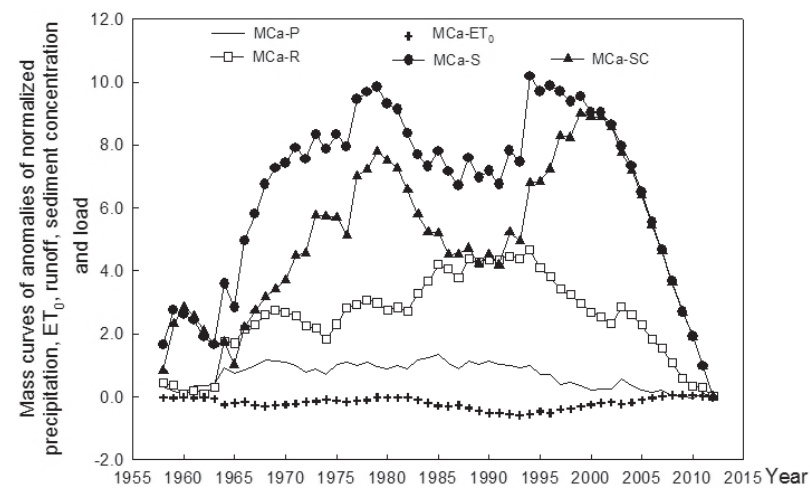

Fig. 4. Mass curves of anomalies of normalized characteristics of ZHS during 1958-2012. 
Table 3. Precipitation and $\mathrm{ET}_{0}$ of the paired years.

\begin{tabular}{|c|c|c|c|c|c|c|c|c|c|c|c|}
\hline \multirow{2}{*}{ No. } & \multicolumn{3}{|c|}{ Paired years with SPEC } & \multicolumn{4}{|c|}{$\mathrm{P} / \mathrm{mm}$} & \multicolumn{4}{|c|}{$\mathrm{ET}_{0} / \mathrm{mm}$} \\
\hline & Year 1 & Year 2 & D-year & Year 1 & Year 2 & D-p & $\mathrm{a}(\%)$ & Year 1 & Year 2 & $\mathrm{D}-\mathrm{ET}_{0}$ & $\mathrm{a}(\%)$ \\
\hline 1 & 1960 & 1977 & -17 & 450.3 & 448.0 & 2.3 & 0.51 & 942.1 & 943.2 & -1.1 & -0.12 \\
\hline 2 & 1965 & 2004 & -39 & 408.6 & 404.8 & 3.8 & 0.93 & 960.2 & 969.5 & -9.3 & -0.97 \\
\hline 3 & 1966 & 1978 & -12 & 583.4 & 585.2 & -1.8 & -0.31 & 946.5 & 938.6 & 7.9 & 0.83 \\
\hline 4 & 1972 & 2004 & -32 & 402.8 & 404.8 & -2.0 & -0.50 & 964.8 & 969.5 & -4.7 & -0.49 \\
\hline 5 & 1979 & 2000 & -21 & 442.3 & 446.1 & -3.8 & -0.86 & 996.8 & 980.7 & 16.1 & 1.62 \\
\hline
\end{tabular}

Note: D-year is the difference in years between Year 1 and 2; D-p is the difference in precipitation between Year 1 and 2; D-ET is the difference in $\mathrm{ET}_{0}$ between Year 1 and 2; and a is the amplitude (\%).

period, and the $\mathrm{ET}_{0}$ was $942.9 \mathrm{~mm}$ higher than the whole period. Mean R, S, and SC were $6.28 \times 10^{8} \mathrm{~m}^{3}$, $0.23 \times 10^{8} \mathrm{t}$, and $41.2 \mathrm{~kg} \mathrm{~m}^{-3}$, respectively - all of which were less than the mean values for the whole period, with a relative decrease of $23.1 \%, 67.0 \%$, and $58.8 \%$, respectively.

\section{Precipitation and $\mathrm{ET}_{0}$ between Paired} Two Years with SPEC

There are five pairs of years with similar weather conditions (Table 3) between the 1960s and 2000s, and the number of years of difference between each pair varies from 12 to 39 . The difference in precipitation and $\mathrm{ET}_{0}$ ranged from -3.8-3.8 $\mathrm{mm}$ and -9.3-16.1 $\mathrm{mm}$, respectively, from the absolute value of the paired years (Table 3), and the difference in precipitation and $\mathrm{ET}_{0}$ from the relative value of the paired years ranged from $-0.86-0.93 \%$ and $-0.97-1.62 \%$, respectively.

\section{Runoff and Sediment Load between Paired Two Years with SPEC}

The SPEC analysis of the changes in runoff (R), sediment load (S), and sediment concentration (SC) are shown in Table 4. In SPEC, when comparing the later year with the earlier year in each pair, three $(2,3$, and 5) of the five pairs showed a reduced $\mathrm{R}$, three $(3,4$, and 5$)$ of the five pairs showed a reduced $\mathrm{S}$, and three $(3,4$ and 5$)$ of the five pairs had a reduced SC. The amplitudes of R,

Table 4. Changes to runoff and sediment load within the five pairs of years with similar precipitation and potential evapotranspiration conditions.

\begin{tabular}{|c|c|c|c|c|c|c|}
\hline Character & No. & 1 & 2 & 3 & 4 & 5 \\
\hline \multirow{2}{*}{$\begin{array}{c}\text { Pairs of years with } \\
\text { SPEC }\end{array}$} & Year 1 & 1960 & 1965 & 1966 & 1972 & 1979 \\
\hline & Year 2 & 1977 & 2004 & 1978 & 2004 & 2000 \\
\hline \multirow{4}{*}{ Runoff $\left(10^{8} \mathrm{~m}^{3}\right)$} & Year 1 & 5.83 & 7.67 & 11.74 & 5.43 & 7.39 \\
\hline & Year 2 & 8.94 & 6.20 & 9.45 & 6.20 & 5.88 \\
\hline & Difference & -3.11 & 1.47 & 2.29 & -0.77 & 1.51 \\
\hline & $\mathrm{a}(\%)$ & -53.4 & 19.2 & 19.5 & -14.1 & 20.4 \\
\hline \multirow{4}{*}{ Sediment load $\left(10^{8} \mathrm{t}\right)$} & Year 1 & 0.62 & 0.19 & 2.20 & 0.46 & 0.83 \\
\hline & Year 2 & 1.77 & 0.28 & 0.86 & 0.28 & 0.34 \\
\hline & Difference & -1.15 & -0.09 & 1.34 & 0.18 & 0.49 \\
\hline & a $(\%)$ & -185.5 & -47.8 & 60.8 & 39.6 & 58.9 \\
\hline \multirow{4}{*}{$\begin{array}{l}\text { Sediment concentration } \\
\qquad\left(\mathrm{kgm}^{-3}\right)\end{array}$} & Year 1 & 154.0 & 27.5 & 219.0 & 109.0 & 158.0 \\
\hline & Year 2 & 290.0 & 44.4 & 119.0 & 44.4 & 87.2 \\
\hline & Difference & -136.0 & -16.9 & 100.0 & 64.6 & 70.8 \\
\hline & a $(\%)$ & -88.3 & -61.5 & 45.7 & 59.3 & 44.8 \\
\hline
\end{tabular}

Note: a is amplitude (\%) 


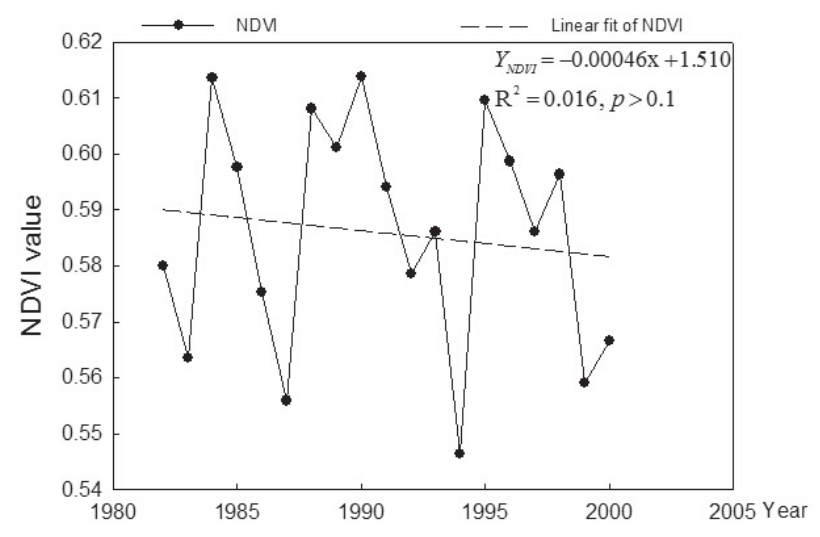

Fig. 5. Change rate of NDVI in upstream area of ZHS from 1982 to 2000 .

$\mathrm{S}$, and SC between the paired years ranged from -53.4$20.4 \%,-185.5-60.8 \%$, and $-88.3-59.3 \%$, respectively. The $\mathrm{R}, \mathrm{S}$, and SC for pair (1) showed the most dramatic change among the five pairs, with amplitudes of R, S, and SC of $-53.4 \%,-185.5 \%$, and $-88.3 \%$, respectively.

\section{An Example of NDVI Change in Pair 5}

Because precipitation and potential evapotranspiration are similar between the paired years, the effects on R, S, and SC can be attributed primarily to human activity. We selected pair No. 5 (years 1979 and 2000, see Table 3) with runoff, sediment load, and sediment concentration amplitudes of $20.43 \%, 58.89 \%$, and $44.81 \%$, respectively, as an example, and applied the NDVI data to further confirm the applicability of the SPEC method to analyzing the influence of human activity on the runoff and sediment load of a river. NDVI is a sensitive indicator of green plant material and an index of the vegetation cover of a region [41], which directly affects the water yield and sediment load. Considering availability of data on NDVI, we analyzed NDVI data in 1982 and 2000 for pair No. 5. Annual NDVI had no significant trends with a linear decline from 1982 to 2000 (Fig. 5). The mean annual NDVIs for 1982 and 2000 were 0.580 and 0.567 , respectively. NDVI decreased $57.87 \%$, and increased by $42.13 \%$ in terms of the area. The vegetation cover increased mainly in the upper and the lower reaches of the Beiluo River (Fig. 6), which may be the main reason for the runoff reduction in the Beiluo River Basin [42, 43].

\section{Soil and Water Conservation Engineering}

Runoff, sediment load, and sediment concentration of the Beiluo River are also influenced by engineering besides NDVI changes. Soil and Water Conservation Data Compilation of the Yellow River Basin (Table 5) showed that 42 reservoirs (all of them in Shaanxi) are distributed in the upstream area of ZHS, and totally controlled an area of $2482.2 \mathrm{~km}^{2}$. The amount of siltation measured was $0.43 \times 10^{8} \mathrm{~m}^{3}$ in the reservoirs, and the key projects for gully control and check dam were $0.25 \times 10^{8} \mathrm{~m}^{3}$ and $12.9 \times$ $10^{8} \mathrm{~m}^{3}$, respectively. Based on this volume and the dry bulk density of sediment $\left(1.35 \mathrm{t} \mathrm{m}^{-3}\right.$ [44]), the total sediment amount was estimated to be $18.33 \times 10^{8} \mathrm{t}$. Considering the 40 -year period between the start of the implementation and 1999 , the 40-year average sediment amount was found to be $0.46 \times 10^{8} \mathrm{t} / \mathrm{yr}$, which accounted for $64.9 \%$ of the mean sediment amount $\left(0.71 \times 10^{8} \mathrm{t} / \mathrm{yr}\right)$ in the Beiluo River Basin (Table 2). The total amount of siltation $\left(18.33 \times 10^{8} \mathrm{t}\right)$, or the annual average $\left(0.46 \times 10^{8} \mathrm{t} / \mathrm{yr}\right)$, may explain the decreased trend of sediment load in Fig. 2. In addition, areas had been largely covered by planted forest and grassland by 1999, it was shown that areas of arbor, shrub, economic trees, and grass were 262.33, 259.12, 92.71, and 146.42 thousand hectares, respectively (soil and water conservation data compilation of the Yellow River Basin). Therefore, soil and water control functions in these areas were attributed to the vegetation coverage, and the soil
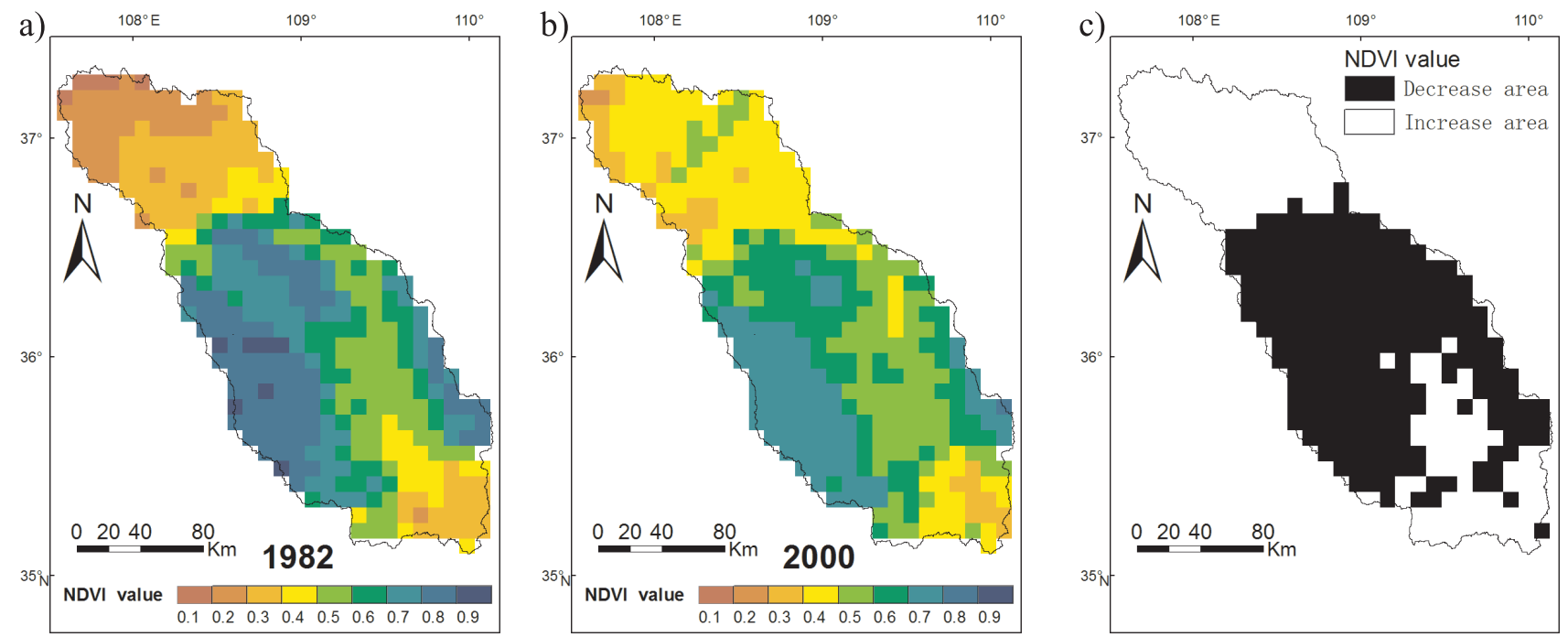

Fig. 6. NDVI change of upstream area of ZHS in 1982 and 2000. 
Table 5. Engineering measures of the ZHS upstream area before 1999.

\begin{tabular}{|c|c|c|c|c|}
\hline Type & Character & Unit & Shaanxi & Amount \\
\hline \multirow{5}{*}{ Reservoir } & Number & Set & 42 & 42 \\
\hline & Control Area & $\mathrm{km}^{2}$ & 2482.2 & 2482.2 \\
\hline & Capacity & $10^{8} \mathrm{~m}^{3}$ & 1.72 & 1.72 \\
\hline & Siltation & $10^{8} \mathrm{~m}^{3}$ & 0.43 & 0.43 \\
\hline & & $10^{8} \mathrm{t}$ & 0.58 & 0.58 \\
\hline \multirow{5}{*}{ Key projects for gully control } & Number & Set & 34 & 34 \\
\hline & Control Area & $\mathrm{km}^{2}$ & 456.9 & 456.9 \\
\hline & Capacity & $10^{8} \mathrm{~m}^{3}$ & 0.50 & 0.50 \\
\hline & Siltation & $10^{8} \mathrm{~m}^{3}$ & 0.25 & 0.25 \\
\hline & & $10^{8} \mathrm{t}$ & 0.34 & 0.34 \\
\hline \multirow{3}{*}{ Check dam } & Number & Set & 1326 & 1326 \\
\hline & Siltation & $10^{8} \mathrm{~m}^{3}$ & 12.90 & 12.90 \\
\hline & & $10^{8} \mathrm{t}$ & 17.42 & 17.42 \\
\hline \multirow{2}{*}{\multicolumn{2}{|c|}{ Total amount of siltation }} & $10^{8} \mathrm{~m}^{3}$ & 13.58 & 13.58 \\
\hline & & $10^{8} \mathrm{t}$ & 18.33 & 18.33 \\
\hline
\end{tabular}

erosion of land - where vegetation coverage was more than $70 \%$ - would be well controlled [45].

\section{Discussion}

This paper selected discrete time periods based on similar weather conditions to analyze the effects of human activities on runoff and erosion. This way ensured a relative uniformity for precipitation that generates runoff and erosion, but also improved the objectivity and accuracy of the data analysis and, therefore, the results. Compared with the traditional hydrological method, this method does not use distinct transition points for a hydrological series to divide the study period, which avoids divergence resulting from the different dividing of "unaffected" hydrological series period $[13,14]$. Once this condition for the runoff and sediment yield is followed, analyzing the variation of runoff and sediment load at a watershed hydrological control station can help identify impacts on runoff and erosion between natural and human factors by applying the traditional statistics and basic principles of hydrology, and reducing the influence of the calibration of key parameters in a distributed hydrological model [15]. In addition, the results from this method can be compared to and verify the results from a distributed hydrological model, and improve our understanding of the anthropogenic influence on runoff and erosion.

The result of annual runoff in the Beiluo River had a significant downtrend during the study period, which is consistent with previous studies [16, 46, 47]. Another reason for this is the regulation of 42 reservoirs [16, $23,46]$. In addition, the "rainwater collection project" implemented in the Wei River Basin has also contributed to runoff reduction since 1996, during which two million small cisterns were built to collect storm water to provide drinking water and irrigation. Nearly $6 \times 10^{6} \mathrm{~m}^{3}$ of precipitation has been collected each year, including the rainfall of events that did not produce runoff [48]. The sediment concentration decreased during the study period. The reason for this may be the basin landscape pattern change [49]. In paired years set No. 5, runoff, sediment load and sediment concentration decreased, while the NDVI value also decreased. The reason is the NDVI, which mainly shows the vegetation cover, and the change of vegetation cover were only a part of human activities. More data were added to the analysis (land use data for example) could maybe explain this.

This method avoids the assumption of "no or less impact from human activities" [20]. In terms of detecting the "baseline period" $[16,17,18,19]$, the method employed in this study appears be more advanced than the traditional double mass curve. For instance, as shown in $[16,17]$, a good baseline period can be found for the double mass curve of precipitation and sediment load of the Wei River. Furthermore, it was shown in reference [17] that the multiple $\mathrm{R}$ of the relationships between accumulative precipitation and sediment load were very close to 1 (extremely significant) in the first several years. They should therefore be considered as one baseline period. However, the detected break-year in reference [16] was totally different from that detected in reference [17]. Such a difference may be explained as follows: in double mass curve method, a period of several years, when accumulative precipitation and sediment load has a very good linear relationship $\left(\mathrm{R}^{2}>0.99\right)$, is usually employed 
as a baseline period in order to determine the impact of human activities. This inevitably brings about an issue that if the multiple $\mathrm{R}$ reaches 0.99 or higher, any time period can be selected as the baseline period. Then it will be difficult to determine which period is the best baseline period if we choose the double mass curve method.

There are two alternatives for the analysis of the influence of human activities using the similar weather condition analysis method. The first is considering the effect of human activities on runoff and erosion as a whole, and not distinguishing between different human activities. If more data were available, the effect of the different types of activity, such as irrigation and industrial water consumption, could be distinguished in the runoff and sediment load. The second option is to consider the same human activities occurring in the paired years as a net change instead of as a new effect on runoff and erosion, which makes it easier to describe the influence of human activities between the paired years.

On the Loess Plateau, the main surface runoff and erosion are generated by rainstorms characterized by high intensity and short duration. When the scale of the data and time was the same, the similar weather condition analysis method could also be applied to daily analysis. Furthermore, the selection of thresholds is flexible. The smaller the threshold and the fewer paired years, the better the accuracy of the results. Finally, if more hydrological data, such as soil water storage and underground runoff, were available, the accuracy of the results from this similar weather condition analysis method would be improved. Because of the complexity of geological processes, there are also some obvious disadvantages for the method adopted here, such as the lack of physical mechanism in this method when describing changes to geography. If more methods such as model simulation were combined with the similar weather condition analysis, this would help clarify the variability in the characteristics and influencing factors of the hydrological and sedimentary elements.

\section{Conclusions}

The river annual sediment concentration, annual runoff, and sediment load had significant trends during 1958-2012. There was significant $(\mathrm{P}<0.001)$ synchronized variation both between the annual runoff and sediment load, and annual sediment concentration and sediment load.

The stages of river runoff and sediment load could be divided according to mass curves of anomalies of observed data, and the mass curves of normalized characteristics could put all change processes in one plot for better analysis. Four clear stages of runoff and sediment load change were detected.

We selected five pairs of years ranging from the 1960s to the 2000s using the SPEC method. Three of the five pairs showed a reduced runoff and sediment load, and this was consistent with the trend detected by regression analysis. For the three consecutive years with SPEC, 12 of the 18 pairs showed reduced runoff, and 13 of the 18 pairs had a reduced sediment load (see supplementary material). For the five consecutive years with SPEC, eight of the 12 pairs showed reduced runoff, and 10 of the 12 pairs had a reduced sediment load (see supplementary material). This means that the reduction in the sediment load of the Beiluo River Basin caused by human activities occurs in most of the time period studied. The extent of the decrease in runoff and sediment load caused by human activities was related to the compared time period. That is, the variability of runoff and sediment load caused by human activities varied in different pair periods.

The human impacts related to NDVI change, and soil and water measures in the basin were important. Not only was there a change of sloping cropland into non-food crop vegetation or cultivable terraces, but also $18.33 \times 10^{8} \mathrm{t}$ of silt trapped in reservoirs and behind check dams during 1960-99.

\section{Acknowledgements}

This research was funded by the National Science Foundation of China (Nos. 41171420, 41271295, and 41371277), the Key Research Program of the Chinese Academy of Sciences (No. KZZD-EW-04), and the West Light Foundation of the Chinese Academy of Sciences (No. 2013-165-04).

\section{References}

1. WU Y.P., CHEN J. Modeling of soil erosion and sediment transport in the East River Basin in southern China. Sci. Total Environ. 441, 159, 2012.

2. WALLING D.E., FANG D. Recent trends in the suspended sediment loads of the world's rivers. Global Planet. Change, 39, (1-2), 111, 2003.

3. SIAKEU J., OGUCHI T., AOKI T., ESAKI Y., JARVIE H.P. Change in riverine suspended sediment concentration in central Japan in response to late 20th century human activities. Catena, 55 (2), 231, 2004.

4. FANOS A.M. The impact of human activities on the erosion and accretion of the Nile Delta coast. J. Coastal Res., 11 (3), 821, 1995.

5. CARRIQUIRY J.D., SANCHEZ A. Sedimentation in the Colorado River delta and upper gulf of California after nearly a century of discharge loss. Mar. Geol., 158 (1), 125, 1999.

6. XU J.X. Plausible causes of temporal variation in suspended sediment concentration in the upper Changjiang River and major tributaries during the second half of the 20th century. Quatern. Int., 208 (1-2), 85, 2009.

7. MIAO C.Y., NI J.R., BORTHWICK A.G.L., YANG L. A preliminary estimate of human and natural contributions to the changes in water discharge and sediment load in the Yellow River. Global Planet. Change, 76, (3-4), 196, 2011.

8. XU H.L., ZHOU B., SONG Y.D. Impacts of climate change on headstream runoff in the Tarim River Basin. Hydrol. Res., 42 (1), 20, 2011.

9. MU X.M., ZHANG X.Q., SHAO H.B., GAO P., WANG 
F., JIAO J.Y., ZHU J.L. Dynamic Changes of Sediment Discharge and the Influencing Factors in the Yellow River, China, for the Recent 90 Years. Clean - Soil, Air, Water, 40 (3), 303, 2012.

10. RESTREPO J.D., SYVITSKI J.P.M. Assessing the Effect of Natural Controls and Land Use Change on Sediment Yield in a Major Andean River: The Magdalena Drainage Basin, Colombia. AMBIO: A J. Hum. Environ., 35 (2), 65, 2006.

11. LØRUP J.K., REFSGAARD J.C., MAZVIMAVI D. Assessing the effect of land use change on catchment runoff by combined use of statistical tests and hydrological modelling: case studies from Zimbabwe. J. Hydrol., 205, (34), 147, 1998.

12. NEARING M.A., JETTEN V., BAFFAUT C., CERDAN O., COUTURIER A., HERNANDEZ M., LE BISSONNAIS Y., NICHOLS M.H., NUNES J.P., RENSCHLER C.S., SOUCHÈRE V., VAN OOST K. Modeling response of soil erosion and runoff to changes in precipitation and cover. Catena, 61, (2-3), 131, 2005.

13. QIN W., ZHU Q.K., LIU G.Q., ZHANG Y. Regulation effects of runoff and sediment of ecological conservation in the upper reaches of Beiluo River. J. Hydraul. Eng., 41 (11), 1325, 2010.

14. LIU E.J., ZHANG X.P., XIE M.L., CHEN N., ZHANG T.T., GUO M.J., ZHANG J.J. Hydrologic responses to vegetation restoration and their driving forces in a catchment in the Loess hilly-gully area: A case study in the upper Beiluo River. Acta Ecol. Sin., 35 (3), 1, 2015.

15. CONG Z.T., YANG D.W., GAO B., YANG H.B., HU H.P. Hydrological trend analysis in the Yellow River basin using a distributed hydrological model. Water Resour. Res., 45 (7), W00A13, 2009.

16. 1GAO P., GEISSEN V., RITSEMA C.J., MU X.M., WANG F. Impact of climate change and anthropogenic activities on stream flow and sediment discharge in the Wei River basin, China. Hydrol. Earth Syst. Sc., 17 (3), 961, 2013.

17. XIN Z.B., YU B.F., HAN Y.G. Spatiotemporal Variations in Annual Sediment Yield from the Middle Yellow River, China, 19502010. J. Hydrol. Eng., 20 (8), 04014090-1, 2015.

18. BAŽATOVÁ T., ŠIMKOVÁ J. Changes in Runoff Regime. The Lomnice Catchment Case Study. Soil \& Water Res., 10 (1), 40, 2015.

19. LI F.P., ZHANG G.X., XU Y.J. Separating the Impacts of Climate Variation and Human Activities on Runoff in the Songhua River Basin, Northeast China. Water, 6 (11), 3320, 2014.

20. DONG W., CUI B.S., LIU Z.H., ZHANG K.J. Relative effects of human activities and climate change on the river runoff in an arid basin in northwest China. Hydrol. Process., 28 (18), 4854, 2014.

21. ZHAO G.J., TIAN P., MU X.M., JIAO J.Y., WANG F., GAO P. Quantifying the impact of climate variability and human activities on streamflow in the middle reaches of the Yellow River basin, China. J. Hydrol., 519, 387, 2014.

22. FU B.J., GULINCK H. Land evaluation in an area of severe erosion: The Loess Plateau of China. Land Degrade. Dev., 5 (1), 33, 1994.

23. RAN D.C., LIU B., WANG H., LUO Q.H., MA Y. Soil and water conservation measures and their benefits in runoff and sediment reductions of typical tributary in the middle of Yellow River. The Yellow River Water Conservancy Press: Zhengzhou, 275, 2006.

24. PETERSON T.C., EASTERLING D.R., KARL T.R., GROISMAN P., NICHOLLS N., PLUMMER N., TOROK S., AUER I., BÖHM R., GULLETT D., VINCENT L., HEINO R., TUOMENVIRTA H., MESTRE O., SZENTIMREY
T., SALINGER J., FØRLAND E.J., HANSSEN-BAUER I., ALEXANDERSSON H., JONES P., PARKER D. Homogeneity adjustments of situ atmospheric climate data: a review. Int. J. Climatol., 18 (13), 1493, 1998.

25. ALLEN R.G., PEREIRA L.S., RAES D., SMITH M. Crop evapotranspiration guidelines for computing crop water requirements. FAO Irrigation and Drainage Paper 56, Rome, 1998.

26. TUCKER C.J., PINZON J.E., BROWN M.E., SLAYBACK D.A., PAK E. W., MAHONEY R., VERMOTE E.F., SALEOUS N.E. An extended AVHRR 8-km NDVI data set compatible with MODIS and SPOT vegetation NDVI data. Int. J. Remote Sens., 26 (20), 4485, 2005.

27. STOW D., PETERSEN A., HOPE A., ENGSTROM R., COULTER L. Greenness trends of Arctic tundra vegetation in the 1990s: Comparison of two NDVI data sets from NOAA AVHRR systems. Int. J. Remote Sens., 28 (21), 4807, 2007.

28. ZHOU L., KAUFMANN R.K., TIAN Y., MYNENI R.B., TUCKER C.J. Relation between interannual variations in satellite measures of northern forest greenness and climate between 1982 and 1999. J. Geophys. Res.: Atmos., 108, (D1), ACL3 1, 2003.

29. SHANGGUAN Z.P., ZHENG S.X. Ecological properties of soil water and effects on forest vegetation in the Loess Plateau. Int. J. Sust. Dev. World., 13 (4), 307, 2006.

30. GATES J.B., SCANLON B.R., MU X.M., ZHANG L. Impacts of soil conservation on groundwater recharge in the semi-arid Loess Plateau, China. Hydrogeol. J., 19 (4), 865, 2011.

31. ZHU T.X., CAI Q.G., ZENG B.Q. Runoff generation on a semi-arid agricultural catchment: field and experimental studies. J. Hydrol., 196 (1-4), 99, 1997.

32. GAO G., CHEN D.L., REN G.Y., CHEN Y., LIAO Y.M. Spatial and temporal variations and controlling factors of potential evapotranspiration in China: 1956-2000. J. Geogr. Sci., 16 (1), 3, 2006.

33. JOURNEL A.G., HUIJBREGTS C.J. Mining Geostatistics. Academic Press: London, 25, 1978.

34. BURROUGH P.A., MCDONNELL R.A. Principles of Geographical Information Systems. Oxford University Press: Oxford, 1, 1998.

35. IORGULESCU I., BEVEN K.J. Nonparametric direct mapping of rainfall-runoff relationships: An alternative approach to data analysis and modeling?. Water Resour. Res., 40 (8), W08403, 2004.

36. ZHOU G.Y., WEI X.H., WU Y.P., LIU S.G., HUANG Y.H., YAN J.H., ZHANG D.Q., ZHANG Q.M., LIU J.X., MENG Z., WANG C.L., CHU G.W., LIU S.Z., TANG X.L., LIU X.D. Quantifying the hydrological responses to climate change using an intact forested small watershed in southern China. Global Change Biol., 17 (12), 3736, 2011.

37. WU Y.P., CHENG D.S., YAN W.D., LIU S G., XIANG W.H., CHEN J., HU Y.M., WU Q. Diagnosing climate change and hydrological responses in the past decades for a minimallydisturbed headwater basin in South China. Water Resour. Manag., 28 (12), 4385, 2014.

38. WANG F., MU X.M., HESSEL R., ZHANG W.S., RITSEMA C.J., LI R. Runoff and Sediment load of the Yan River, China: changes over the last $60 \mathrm{yr}$. Hydrol. Earth Syst Sci., 17 (7), 2515, 2013.

39. WANG F., MU X.M., LI R., JIAO J.Y. Change Characteristic of the Runoff and Sediment under the Similar Precipitation Condition in the Beiluohe River. J. Water Resour. Water Eng., 19 (6), 36, 2008.

40. LI Z., ZHENG F.L., LIU W.Z. Analyzing the Spatial temporal Changes of Extreme Precipitation Events in the 
Loess Plateau from 1961 to 2007. J. Nat. Resour., 25 (2), 291, 2010.

41. CARLSON T.N., GILLIES R.R., PERRY E.M. A method to make use of thermal infrared temperature and NDVI measurements to infer surface soil water content and fractional vegetation cover. Remote Sens. Rev., 9 (1-2), 161, 1994.

42. CHEN N., LI T.B., ZHANG X.P., CHOU S.R., XIE M.L., LIU E.J. Spatiotemporal variation of vegetation coverage in Beiluo River watershed based on remote sensing data analysis. B.Soil Water Conserv., 33 (3), 206, 2013.

43. WANG X.Y., BI H.X., SONG Q.F., LU S.W., Influence of forest coverage on basin runoff in China 's Loess Plateau. Pol. J. Environ. Stud, 24 (2), 743, 2015.

44. RAN D.C., LUO Q.H., LIU B., WANG H. Effect of soil retaining dams on flood and sediment reduction in middle reaches of Yellow River. J. Hydraul Eng., 5, 7, 2004.
45. JIAO J.Y., WANG W.Z., LI J. Effective cover rate of woodland and grassland for soil and water conservation. Acta Phytoecologica Sin., 24 (5), 608, 2000.

46. MO L., MU X.M., WANG Y., WANG F., LI L.D. Change of runoff and sediment of Beiluo River and reason analysis. J Sediment Res., 6, 30, 2009.

47. DU J., SHI C.X. Effects of climatic factors and human activities on runoff of the Weihe River in recent decades. Quatern. Int., 282, 58, 2012.

48. SU X.L., KANG S.Z., WEI X.M., XING D.W., CAO D.W. Impact of climate change and human activity on the runoff of Wei River basin to the Yellow River. J. Northwest A \& F Univ. (Nat. Sci. E.), 35, 153, 2007.

49. SUO A. N., HONG J., LIN Y., GE J. P. Relationships between soil and water loss and landscape pattern on Loess Plateau. Chin J. Appl. Ecol., 16 (9), 1719, 2005. 


\section{Supplementary Material}

Precipitation and $\mathrm{ET}_{0}$ between Three Consecutive Years with SPEC

The 18 pairs of years based on similar weather conditions (appendix Table 1) range from the 1960s to the 2000 s, and the number of years of difference between each pair varies from 5 to 51 . The differences in precipitation $(\mathrm{P})$ and $\mathrm{ET}_{0}$ ranged from -5.7-8.3 $\mathrm{mm}$ and -16.7-17.6 mm, respectively, from the absolute value of the paired period (appendix Table 1), and the difference in precipitation and $\mathrm{ET}_{0}$ from the relative value of the paired period ranging from $-1.08-1.83 \%$ and $-1.74-1.83 \%$, respectively.

\section{Runoff and Sediment Load between Paired Three Consecutive Years with SPEC}

The SPEC analysis of the changes in runoff (R), sediment load (S) and sediment concentration (SC) are shown in Table 2 (appendix). In SPEC, when comparing the later period with the earlier period in each pair, 12 (2, $4,7,9,10,11,13,14,15,16,17$, and 18) of the 18 pairs showed reduced $\mathrm{R}, 13(1,2,4,6,7,8,9,10,13,14,16$, 17 , and 18) of the 18 pairs showed reduced $\mathrm{S}$, and 13 (1, $2,3,4,6,7,9,10,13,14,16,17$, and 18) of the 18 pairs had reduced SC. The amplitudes of R, S, and SC between the paired years ranged from $-35.7-44.3 \%,-116.7-96.9 \%$, and $-43.2-96.5 \%$, respectively. The R, S, and SC for pair No. 14 showed the most dramatic change among the 18 pairs, with amplitudes of R, S, and SC of $44.3 \%, 96.9 \%$, and $96.5 \%$, respectively.

Precipitation and $\mathrm{ET}_{0}$ between Five Consecutive Years with SPEC

The 12 pairs of years based on similar weather conditions (appendix Table 3) range from the 1960s to the 2000 s, and the number of years of difference between each pair varies from 6 to 37. The difference in precipitation and $\mathrm{ET}_{0}$ ranged from -8.6-6.8 $\mathrm{mm}$ and -16.7-5.2 $\mathrm{mm}$, respectively, from the absolute value of the paired period (appendix Table 3), and the difference in precipitation and $\mathrm{ET}_{0}$ from the relative value of the paired period ranged from $-1.83-1.23 \%$ and $-1.84-0.57 \%$, respectively.

Table 1. (appendix) Precipitation and $\mathrm{ET}_{0}$ of the three consecutive years.

\begin{tabular}{|c|c|c|c|c|c|c|c|c|c|c|c|}
\hline \multirow[b]{2}{*}{ No. } & \multicolumn{3}{|c|}{ Paired periods with SPEC } & \multicolumn{4}{|c|}{$\mathrm{P} / \mathrm{mm}$} & \multicolumn{4}{|c|}{$\mathrm{ET}_{0} / \mathrm{mm}$} \\
\hline & Period 1 & Period 2 & D- Periods & Period 1 & Period 2 & D-p & $a(\%)$ & Period 1 & $\begin{array}{c}\text { Period } \\
2\end{array}$ & $\mathrm{D}-\mathrm{ET}_{0}$ & $a(\%)$ \\
\hline 1 & $1958-1960$ & $1965-1967$ & -7 & 527.1 & 522.9 & 4.2 & 0.80 & 913.8 & 913.2 & 0.6 & 0.07 \\
\hline 2 & $1958-1960$ & 2009-2011 & -51 & 527.1 & 527.6 & -0.5 & -0.09 & 913.8 & 908.3 & 5.5 & 0.60 \\
\hline 3 & $1959-1961$ & 1976-1978 & -17 & 527.6 & 533.3 & -5.7 & -1.08 & 915.3 & 918.9 & -3.6 & -0.39 \\
\hline 4 & $1959-1961$ & 2009-2011 & -50 & 527.6 & 527.6 & 0.0 & 0.00 & 915.3 & 908.3 & 7.0 & 0.76 \\
\hline 5 & $1960-1962$ & $1968-1970$ & -8 & 541.9 & 536.2 & 5.7 & 1.05 & 924.5 & 922.5 & 2.0 & 0.22 \\
\hline 6 & $1961-1963$ & $1981-1983$ & -20 & 573.2 & 566.3 & 6.9 & 1.20 & 899.9 & 894.6 & 5.3 & 0.59 \\
\hline 7 & $1965-1967$ & $2010-2012$ & -45 & 522.9 & 517.3 & 5.6 & 1.07 & 913.2 & 902.3 & 10.9 & 1.19 \\
\hline 8 & 1967-1969 & $1975-1977$ & -8 & 565.8 & 565.0 & 0.8 & 0.14 & 889.1 & 901.8 & -12.7 & -1.43 \\
\hline 9 & $1967-1969$ & $1981-1983$ & -14 & 565.8 & 566.3 & -0.5 & -0.09 & 889.1 & 894.6 & -5.5 & -0.62 \\
\hline 10 & $1969-1971$ & $2007-2009$ & -38 & 488.5 & 489.0 & -0.5 & -0.10 & 941.3 & 944.5 & -3.2 & -0.34 \\
\hline 11 & $1971-1973$ & 1994-1996 & -23 & 482.7 & 480.7 & 2.0 & 0.41 & 949.1 & 939.3 & 9.8 & 1.03 \\
\hline 12 & $1972-1974$ & 1993-1995 & -21 & 465.0 & 464.9 & 0.1 & 0.02 & 961.0 & 943.4 & 17.6 & 1.83 \\
\hline 13 & $1977-1979$ & $2005-2007$ & -28 & 491.8 & 492.4 & -0.6 & -0.12 & 959.5 & 976.2 & -16.7 & -1.74 \\
\hline 14 & $1977-1979$ & 2007-2009 & -30 & 491.8 & 489.0 & 2.8 & 0.57 & 959.5 & 944.5 & 15.0 & 1.56 \\
\hline 15 & 1986-1988 & 1991-1993 & -5 & 477.7 & 477.7 & 0.0 & 0.00 & 895.9 & 896.7 & -0.8 & -0.09 \\
\hline 16 & 1996-1998 & $2008-2010$ & -12 & 472.2 & 472.9 & -0.7 & -0.15 & 941.0 & 926.9 & 14.1 & 1.50 \\
\hline 17 & 1997-1999 & 2004-2006 & -7 & 452.8 & 444.5 & 8.3 & 1.83 & 977.2 & 979.1 & -1.9 & -0.19 \\
\hline 18 & $1998-2000$ & 2006-2008 & -8 & 485.1 & 487.7 & -2.6 & -0.54 & 962.2 & 963.2 & -1.0 & -0.10 \\
\hline
\end{tabular}

Note: D-periods is the difference in years between periods 1 and 2; D-p is the difference in precipitation between periods 1 and 2; $\mathrm{D}-\mathrm{ET}_{0}$ is the difference in $\mathrm{ET}_{0}$ between periods 1 and 2; and a is the amplitude (\%). 
Table 2. (appendix) Changes to runoff and sediment load within the 18 pairs of periods with SPEC.

\begin{tabular}{|c|c|c|c|c|c|c|c|c|c|c|c|c|c|c|}
\hline Type & \multicolumn{2}{|c|}{ Pairs of periods } & \multicolumn{4}{|c|}{$\mathrm{R}\left(10^{8} \mathrm{~m}^{3}\right)$} & \multicolumn{4}{|c|}{$S\left(10^{8} t\right)$} & \multicolumn{4}{|c|}{$\mathrm{SC}\left(\mathrm{kg} \mathrm{m}^{-3}\right)$} \\
\hline No. & P1 & $\mathrm{P} 2$ & P1 & P2 & $\mathrm{D}$ & a (\%) & $\mathrm{P} 1$ & $\mathrm{P} 2$ & $\mathrm{D}$ & a (\%) & P1 & $\mathrm{P} 2$ & $\mathrm{D}$ & $\mathrm{a}(\%)$ \\
\hline 1 & $1958-1960$ & $1965-1967$ & 8.38 & 9.62 & -1.24 & -14.80 & 1.33 & 1.23 & 0.10 & 7.39 & 195.3 & 132.8 & 62.5 & 32.00 \\
\hline 2 & $1958-1960$ & 2009-2011 & 8.38 & 6.02 & 2.36 & 28.21 & 1.33 & 0.07 & 1.26 & 94.88 & 195.3 & 10.7 & 184.6 & 94.52 \\
\hline 3 & $1959-1961$ & 1976-1978 & 7.56 & 10.26 & -2.70 & -35.74 & 0.89 & 1.02 & -0.13 & -14.94 & 158.1 & 150.0 & 8.1 & 5.12 \\
\hline 4 & $1959-1961$ & 2009-2011 & 7.56 & 6.02 & 1.54 & 20.42 & 0.89 & 0.07 & 0.82 & 92.36 & 158.1 & 10.7 & 147.4 & 93.23 \\
\hline 5 & 1960-1962 & $1968-1970$ & 7.42 & 9.17 & -1.75 & -23.72 & 0.50 & 1.09 & -0.59 & -116.73 & 92.4 & 132.3 & -39.9 & -43.18 \\
\hline 6 & 1961-1963 & 1981-1983 & 8.76 & 9.62 & -0.86 & -9.90 & 0.48 & 0.33 & 0.15 & 31.58 & 60.7 & 42.6 & 18.1 & 29.82 \\
\hline 7 & $1965-1967$ & 2010-2012 & 9.62 & 6.59 & 3.03 & 31.47 & 1.23 & 0.07 & 1.16 & 94.06 & 132.8 & 11.2 & 121.6 & 91.57 \\
\hline 8 & $1967-1969$ & $1975-1977$ & 9.84 & 11.14 & -1.30 & -13.28 & 1.25 & 1.08 & 0.17 & 13.68 & 140.7 & 142.9 & -2.2 & -1.56 \\
\hline 9 & $1967-1969$ & 1981-1983 & 9.84 & 9.62 & 0.22 & 2.21 & 1.25 & 0.33 & 0.92 & 74.00 & 140.7 & 42.6 & 98.1 & 69.72 \\
\hline 10 & 1969-1971 & 2007-2009 & 8.10 & 4.78 & 3.32 & 40.98 & 0.98 & 0.04 & 0.94 & 96.32 & 143.7 & 6.7 & 137.0 & 95.34 \\
\hline 11 & $1971-1973$ & 1994-1996 & 6.83 & 6.56 & 0.27 & 4.00 & 0.92 & 1.27 & -0.35 & -38.18 & 169.3 & 176.7 & -7.4 & -4.37 \\
\hline 12 & $1972-1974$ & 1993-1995 & 6.12 & 7.12 & -1.00 & -16.33 & 0.70 & 1.15 & -0.45 & -65.28 & 141.9 & 153.7 & -11.8 & -8.32 \\
\hline 13 & $1977-1979$ & $2005-2007$ & 8.59 & 5.25 & 3.34 & 38.90 & 1.15 & 0.08 & 1.07 & 93.41 & 189.0 & 14.0 & 175.0 & 92.59 \\
\hline 14 & $1977-1979$ & 2007-2009 & 8.59 & 4.78 & 3.81 & 44.34 & 1.15 & 0.04 & 1.11 & 96.88 & 189.0 & 6.7 & 182.3 & 96.46 \\
\hline 15 & 1986-1988 & 1991-1993 & 8.62 & 8.26 & 0.36 & 4.14 & 0.66 & 0.77 & -0.11 & -17.81 & 83.5 & 114.3 & -30.8 & -36.89 \\
\hline 16 & 1996-1998 & $2008-2010$ & 5.85 & 4.91 & 0.94 & 15.96 & 0.63 & 0.06 & 0.57 & 90.98 & 146.5 & 9.5 & 137.0 & 93.52 \\
\hline 17 & 1997-1999 & 2004-2006 & 5.86 & 5.38 & 0.48 & 8.14 & 0.63 & 0.14 & 0.49 & 78.10 & 159.1 & 23.6 & 135.5 & 85.17 \\
\hline 18 & $1998-2000$ & 2006-2008 & 6.16 & 4.92 & 1.24 & 20.11 & 0.55 & 0.04 & 0.51 & 92.36 & 119.5 & 8.0 & 111.5 & 93.31 \\
\hline
\end{tabular}

Note: $\mathrm{P} 1$ is period 1, P2 is period 2, $\mathrm{R}$ is runoff, $\mathrm{S}$ is sediment load, $\mathrm{SC}$ is sediment concentration, $\mathrm{D}$ is the difference between period 1 and 2 , and a is amplitude $(\%)$.

Table 3. (appendix) Precipitation and $\mathrm{ET}_{0}$ of the five consecutive years.

\begin{tabular}{|c|c|c|c|c|c|c|c|c|c|c|c|}
\hline \multirow{2}{*}{ No. } & \multicolumn{3}{|c|}{ Paired periods with SPEC } & \multicolumn{3}{c|}{ P/mm } & \multicolumn{4}{c|}{ ET $_{0} / \mathrm{mm}^{\prime}$} \\
\cline { 2 - 13 } & Period 1 & Period 2 & D- Periods & Period 1 & Period 2 & D-p & a(\%) & Period 1 & Period 2 & D-ET & a(\%) \\
\hline 1 & $1958-1962$ & $1966-1970$ & -8 & 551.3 & 553.7 & -2.4 & -0.44 & 914.6 & 909.4 & 5.2 & 0.57 \\
\hline 2 & $1958-1962$ & $1975-1979$ & -17 & 551.3 & 544.5 & 6.8 & 1.23 & 914.6 & 928.2 & -13.6 & -1.49 \\
\hline 3 & $1959-1963$ & $1979-1983$ & -20 & 525.7 & 522.9 & 2.8 & 0.53 & 910.4 & 918.4 & -8.0 & -0.88 \\
\hline 4 & $1965-1969$ & $1973-1977$ & -8 & 537.9 & 537.4 & 0.5 & 0.09 & 914.8 & 924.7 & -9.9 & -1.08 \\
\hline 5 & $1965-1969$ & $1974-1978$ & -9 & 537.9 & 539.4 & -1.5 & -0.28 & 914.8 & 923.9 & -9.1 & -0.99 \\
\hline 6 & $1967-1971$ & $1973-1977$ & -6 & 531.0 & 537.4 & -6.4 & -1.21 & 908.0 & 924.7 & -16.7 & -1.84 \\
\hline 7 & $1969-1973$ & $2006-2010$ & -37 & 488.7 & 491.7 & -3.0 & -0.61 & 946.3 & 943.4 & 2.9 & 0.31 \\
\hline 8 & $1970-1974$ & $2005-2009$ & -35 & 470.6 & 479.2 & -8.6 & -1.83 & 951.2 & 960.3 & -9.1 & -0.96 \\
\hline 9 & $1972-1976$ & $1999-2003$ & -27 & 528.4 & 529.7 & -1.3 & -0.25 & 929.0 & 944.5 & -15.5 & -1.67 \\
\hline 10 & $1977-1981$ & $2002-2006$ & -25 & 504.9 & 506.1 & -1.2 & -0.24 & 941.1 & 948.0 & -6.9 & -0.73 \\
\hline 11 & $1978-1982$ & $2002-2006$ & -24 & 508.0 & 506.1 & 1.9 & 0.37 & 939.0 & 948.0 & -9.0 & -0.96 \\
\hline 12 & $1996-2000$ & $2004-2008$ & -8 & 465.6 & 461.0 & 4.6 & 0.99 & 957.2 & 970.4 & -13.2 & -1.38 \\
\hline
\end{tabular}

Note: D-periods is the difference in years between periods 1 and 2; D-p is the difference in precipitation between periods 1 and 2;

$\mathrm{D}_{-} \mathrm{ET}_{0}$ is the difference in $\mathrm{ET}_{0}$ between periods 1 and 2; and a is amplitude (\%). 
Table 4. (appendix) Changes to runoff and sediment load within the 12 pairs of periods with SPEC.

\begin{tabular}{|c|c|c|c|c|c|c|c|c|c|c|c|c|c|c|}
\hline Type & \multicolumn{2}{|c|}{ Pairs of periods } & \multicolumn{4}{|c|}{$\mathrm{R}\left(10^{8} \mathrm{~m}^{3}\right)$} & \multicolumn{4}{|c|}{$\mathrm{S}\left(10^{8} \mathrm{t}\right)$} & \multicolumn{4}{|c|}{$\mathrm{SC}\left(\mathrm{kg} \mathrm{m}^{-3}\right)$} \\
\hline No. & $\mathrm{P} 1$ & $\mathrm{P} 2$ & $\mathrm{P} 1$ & $\mathrm{P} 2$ & $\mathrm{D}$ & $\mathrm{a}(\%)$ & $\mathrm{P} 1$ & $\mathrm{P} 2$ & $\mathrm{D}$ & $\mathrm{a}(\%)$ & $\mathrm{P} 1$ & $\mathrm{P} 2$ & $\mathrm{D}$ & $\mathrm{a}(\%)$ \\
\hline 1 & $1958-1962$ & $1966-1970$ & 8.31 & 9.74 & -1.43 & -17.23 & 0.97 & 1.35 & -0.38 & -39.05 & 141.8 & 153.6 & -11.8 & -8.32 \\
\hline 2 & $1958-1962$ & $1975-1979$ & 8.31 & 10.06 & -1.75 & -20.98 & 0.97 & 0.99 & -0.02 & -1.23 & 141.8 & 141.1 & 0.7 & 0.49 \\
\hline 3 & $1959-1963$ & $1979-1983$ & 7.95 & 8.51 & -0.56 & -6.97 & 0.71 & 0.43 & 0.28 & 39.60 & 117.0 & 71.7 & 45.3 & 38.72 \\
\hline 4 & $1965-1969$ & $1973-1977$ & 9.79 & 9.28 & 0.51 & 5.20 & 1.23 & 0.98 & 0.25 & 20.54 & 133.7 & 149.1 & -15.4 & -11.52 \\
\hline 5 & $1965-1969$ & $1974-1978$ & 9.79 & 9.64 & 0.15 & 1.52 & 1.23 & 0.90 & 0.33 & 27.06 & 133.7 & 128.7 & 5.0 & 3.74 \\
\hline 6 & $1967-1971$ & $1973-1977$ & 8.88 & 9.28 & -0.40 & -4.46 & 1.12 & 0.98 & 0.14 & 13.18 & 145.4 & 149.1 & -3.7 & -2.54 \\
\hline 7 & $1969-1973$ & $2006-2010$ & 7.48 & 5.00 & 2.48 & 33.12 & 0.93 & 0.06 & 0.87 & 93.76 & 152.2 & 10.1 & 142.1 & 93.36 \\
\hline 8 & $1970-1974$ & $2005-2009$ & 6.65 & 4.86 & 1.79 & 26.95 & 0.79 & 0.05 & 0.74 & 93.81 & 146.1 & 9.3 & 136.8 & 93.63 \\
\hline 9 & $1972-1976$ & $1999-2003$ & 8.57 & 7.52 & 1.05 & 12.27 & 0.71 & 0.50 & 0.21 & 29.21 & 112.9 & 90.5 & 22.4 & 19.84 \\
\hline 10 & $1977-1981$ & $2002-2006$ & 8.20 & 7.00 & 1.20 & 14.51 & 0.87 & 0.22 & 0.65 & 75.40 & 143.1 & 31.4 & 111.7 & 78.06 \\
\hline 11 & $1978-1982$ & $2002-2006$ & 7.82 & 7.00 & 0.82 & 10.35 & 0.55 & 0.22 & 0.33 & 61.05 & 91.4 & 31.4 & 60.0 & 65.65 \\
\hline 12 & $1996-2000$ & $2004-2008$ & 5.87 & 5.29 & 0.58 & 9.85 & 0.61 & 0.10 & 0.51 & 83.31 & 140.9 & 17.6 & 123.3 & 87.51 \\
\hline
\end{tabular}

Note: P1 is period 1, P2 is period 2, R is runoff, $\mathrm{S}$ is sediment load, SC is sediment concentration, $\mathrm{D}$ is the difference between period 1 and 2 , and a is the amplitude (\%).

\section{Runoff and Sediment Load between Paired Five Consecutive Years with SPEC}

The SPEC analysis of the changes in runoff (R), sediment load (S), and sediment concentration (SC) are shown in Table 4 (appendix). In SPEC, when comparing the later period with the earlier period in each pair, eight $(4,5,7,8,9,10,11$, and 12$)$ of the 12 pairs showed reduced
$\mathrm{R}, 10$ (from 3 to 12 ) of the 12 pairs showed reduced $\mathrm{S}$, and nine $(2,3,5,7,8,9,10,11$, and 12) of the 12 pairs had reduced SC. The amplitudes of $\mathrm{R}, \mathrm{S}$, and $\mathrm{SC}$ between the paired years ranged from $-21.0-33.1 \%,-39.1-93.8 \%$ and $-11.5-93.6 \%$, respectively. The R, S, and SC for pair No. 7 showed the most dramatic change among the 12 pairs, with amplitudes of R, S, and SC of $33.1 \%, 93.8 \%$, and $93.4 \%$, respectively. 
